\title{
ESTIMATION OF ATMOSPHERIC AIR POLLUTION AND HEALTH RISK FOR ROSTOV-ON-DON POPULATION
}

\author{
P. Klimov, M. Basilaia \\ Don state technical university. Rostov-on-Don, Russian Federation \\ science-almanac@mail.ru
}

Technogenic pollution of the environment has a negative impact on the health of the population. Atmospheric air is an integral component of the environment, which is associated with the most part of health risks from environmental factors. The risk concept makes it possible to obtain a quantitative assessment of the potential and real danger to public health, implied with the levels of exposure to adverse environmental factors in the real conditions of populated areas. The purpose of the study is to assess the pollution of atmospheric air in connection with the health risk to the population of Rostov-on-Don. Monitoring of atmospheric pollution is carried out at seven fixed stations of the State Environmental Observing Service of the Rostov State Hydrometeorological Service. The average annual and maximum concentrations of eight air pollutants were analyzed. Excess ratio of admissible concentration limit and complex index of air pollution $P$ were used as indicators characterizing air pollution. For risk assessment, the risk of immediate action (reflex effects), chronic intoxication, and carcinogenic risk were calculated.Rostov-on-Don is a large industrial and administrative-territorial center, a transport hub. Motor transport plays the leading role in the atmospheric air pollution of the city. The atmospheric air of Rostov-on-Don is polluted above the permissible hygienic standards. The pollution level in the central part of the city, determined by the indicator $\mathrm{P}$ (average annual concentrations) is in 1.5 times higher than in the relatively clean Northern residential area. The risk of immediate action in the central part of the city is in 3.38 times higher, the risk of chronic intoxication is higher in 2.05 times, compared to the Northern residential community of the city. According to the results of the risk assessment on immediate action and chronic intoxication from air pollution, the most dangerous to the health of the population are suspended substances, nitrogen oxides, carbon monoxide, phenol and formaldehyde. Chromium and formaldehyde mainly contribute to the formation of carcinogenic risks from the air pollution.

Key words: health risk, atmospheric air pollution.

[Климов П.В., Басилаиа М.А. Оценка загрязнения атмосферного воздуха и риск для здоровья населения Ростова-на-Дону]

Техногенное загрязнение окружающей среды оказывает негативное влияние на состояние здоровья населения. Атмосферный воздух является неотъемлемым компонентом окружающей среды, с которым связана наибольшая часть рисков для здоровья от воздействия фракторов окружающей среды. Концепция риска позволяет получить количественную оценку потенциальной и реальной опасности для здоровья населения, имплицированную с уровнями воздействия неблагоприятных факторов среды в реальных условиях населенных мест.Целью исследования является оценка загрязнения атмосферного воздуха в связи с риском для здоровья населения г. Ростова-на-Дону. Наблюдение за загрязнением атмосфреры осуществляется на семи стационарных станциях Государственной службы наблюдений за состоянием окружающей среды Ростовского ЦГМС. Были проанализированы среднегодовые и максимальные концентрации восьми загрязняющих атмосферный воздух веществ. В качестве показателей, характеризующих загрязнение атмосферного воздуха были использованы кратность превышения ПДК и комплексный показатель загрязнения воздуха Р. Для оценки риска рассчитывались риск немедленного действия (рефлекторных эффректов), хронической интоксикации и канцерогенный риск.Ростов-на-Дону является крупным индустриальным и административнотерриториальным центром, транспортным узлом. Ведущую роль в загрязнении атмосфрерного воздуха города играет автомобильный транспорт. Атмосферный воздух Ростова-на-Дону загрязнен выше допустимых гигиенических нормативов. Уровень загрязнения в центральной части города определенный с помощью показателя $\mathrm{P}$ (среднегодовые концентрации) в 1,5 раза выше чем в относительно чистом Северном жилом массиве. Риск немедленного действия в центральной части города выше в 3,38 раза, риск хронической интоксикации выше в 2,05 раза, по сравнению с Северным жилым массивом города. По результатам оценки риска немедленного действия и хронической интоксикации от загрязнения атмосферного воздуха наибольшую угрозу для здоровья населения представляют взвешенные 
вещества, окислы азота, оксид углерода, фенол и формальдегид. В формирование канцерогенного риска от загрязнения атмосферного воздуха основной вклад вносят хром и фрормальдегид.

Ключевые слова: риск для здоровья, загрязнение атмосферного воздуха.

Petr V. Klimov - candidate of Biology, associate professor. Don state technical university. Rostov-on-Don, Russian Federation.

Mariana A. Basilaia - Ph.D., professor. Don state technical university. Rostov-on-Don, Russian Federation.

Климов Петр Валерьевич - кандидат биологических наук, доцент. Донской государственный технический университет. г. Ростов-на-Дону, Россия.

Басилаиамариана Артемовна - доктор фрилософоских наук, профрессор. Донскойгосударственныйтехническийуниверситет. г. Ростов-на-Дону, Россия.

Technogenic pollution of the environment has a negative impact on the health of the population.Multicomponent emissions of industrial enterprises and vehicles lead to an increase in morbidity and mortality in the human population. The contribution of anthropogenic factors to the formation of various pathologies varies in the range from 10 to $60 \%$, depending on the place and conditions of residence [3].Atmospheric air is an integral component of the environment, which is associated with the most part of health risks from environmental factors [6].It remains relevant to study the human health dependence indicators on environmental pollution in industrial and urbanized regions. Damageassessment to the human health is one of the priority areas of human ecology [5]. The concept of risk makes it possible to obtain a quantitative assessment of the potential and real danger to public health, implied with the levels of exposure to adverse environmental factors in the real conditions of populated areas [4].

The purpose of the study is to assess the pollution of atmospheric air in connection with the health risk to the the population of Rostov-on-Don.To characterize air pollution, the data published in the Yearbooks "The state of atmospheric pollution in cities in Russia" [1] and the Environmental Bulletin of the Don were analyzed [7]. Monitoring of atmospheric pollution is carried out at seven fixed stations of the State Environmental Observing Service of the Rostov State Hydrometeorological Service. The stations are subdivided into "urban background", in residential areas (stations NoNo 2, 21, 55), "industrial", near enterprises (stations NoNo. 44, 52), and "auto", in the area with an intensive traffic (stations No. $29,51)$ [7]. The average annual and maximum concentrations of eight air pollutants were analyzed. Excess ratio of admissible concentration limit and complex index of air pollution $P$ were used as indicators characterizing air pollution [2]. For risk assessment, the risk of immediate action (reflex effects), chronic intoxication, and carcinogenic risk were calculated [2]. The risk was defined as individual, representing the probability of health effects manifestation at real concentrations of pollutants in the ambient air.

An immediate risk assessment was carried out for substances, whichMPCm.r. are substantiated by the reflex effect. The risk significance shows the proportion of the population in the area that at the time of reaching the maximum concentrations could experience adverse reflex reactions - a sense of smell, an irritating effect, etc. The risk assessment of chronic nonspecific intoxication was carried out for a period of 70 years, taking into account the assumption that the estimated situation is typical and the detected trends in atmospheric air pollution will persist for a period of seventy years. The same assumption applies to the calculation of carcinogenic risk [2]. Rostov-on-Don is a large industrial and administrative-territorial center, a transport hub [7]. The leading role in the pollution of the atmospheric air of the city is played by road transport [1].Rostov-on-Don refers to the territories with an increased atmospheric pollution potential due to the anticyclonic type of weather, temperature inversions, dust storms. 
Cluster analysis of mean annual concentrations of suspended solids, sulfur dioxide, carbon monoxide and nitrogen dioxide showed that the stations for monitoring atmospheric pollution of Rostov Hydrometeorological Service NoNo 2, 21, 55, 44 and 29 located in different city districts enter in one cluster, and station No 51, situated at the confluence of large highways in the central part of the city refers to the other cluster that is connected with a higher atmosphere air contamination level.The city receives (in the period of 20082013) carbon dioxide in the amount of 85.02 thousand tons / year, nitrogen dioxide - 15.32 thousand tons / year, as well as sulfur dioxide, solid particles and other matter from stationary sources and vehicles. The contribution of motor vehicles comprised $95.8 \%$ of carbon monoxide emissions, $86.3 \%$ of nitrogen dioxide emissions and $93.8 \%$ of total anthropogenic emissions into the air.To assess the risk to public health, three urban areas were selected.Part of the city center, located at the intersection of high-traffic roads (adopted as point I, corresponds to station No. 51 of Rostov Hydrometeorological Service). The territory affected by the industrial site, with enterprises of machine building, metalworking and other industries (point II, corresponds to station No. 52). The residential area in the northern residential area of the city is relatively remote from the industrial centers (point III, corresponds to station No. 55).

The average concentrations for the period of 2008-2013 in the point I exceed MPC in 2,41 times, nitrogen dioxide - in 2,21 times, nitrogen oxide - in 1,76 times, carbon monoxide in 1,22 times. The maximum single concentrations of suspended substances exceed the hygienic standard in 3.83 times, carbon oxide in 3.8 times, nitrogen dioxide in 2.15 times, formaldehyde in 1.76, nitrogen oxide in 1.72, phenol - 1.67 times. At point II, average concentrations of nitrogen dioxide exceed the hygienic standard in 1.26 times, suspended substances in 1.25 times. Maximum concentrations of suspended substances exceed the hygienic standard in 2.36 times, formaldehyde - 1.69 times, carbon oxide 1.68 times, phenol - 1.32 times, nitrogen dioxide - 1.16 times, nitrogen oxide - 1,12 times.At point III, the average concentration of formaldehyde exceeds the MPC in 1.18 times. The maximum concentrations of suspended solids exceed the hygienic standard in 2.1 times, phenol in 1.87 times, formaldehyde in 1.68 times, carbon monoxide in 1.13 times.

The average value of the complex parameter $\mathrm{P}$ of the eight atmospheric admixtures calculated at the average annual concentration at point I comprised 6.51 points, which is estimated as a dangerous degree of atmospheric pollution, at point II - 5.1 points, is estimated as a dangerous degree of atmospheric pollution, and at point III - 4.0 points, is estimated as an alarming degree of air pollution. The indicator $\mathrm{P}$, calculated for the maximum single concentrations at point I comprised 29.44 points, at point II - 19.12 points, at point III - 15.66 points. At all three points, the degree of atmospheric pollution calculated at the maximum single concentrations is estimated as a cause for concern. The results of the health risk assessment are presented in the table.

Individual risk for public health from air pollution in three selected zones of Rostov-on-Don (in unit fractions)

\begin{tabular}{|l|c|c|c|}
\hline & Riskofimmediateaction & Riskofchronicintoxication & Carcinogenicrisk \\
\hline pointl & 0,46 & 0,305 & 0,000293 \\
\hline point II & 0,184 & 0,170 & 0,000259 \\
\hline point III & 0,136 & 0,149 & 0,000276 \\
\hline
\end{tabular}

The total risk of immediate action was determined by the maximum risk of a single admixture among all the harmful substances that affect it. In points I and II, the risk of immediate action is determined by the effect of carbon monoxide on the population, and at 
point III - suspended substances. At point I, the contribution of suspended solids to the formation of the risk of chronic intoxication comprised $24.38 \%$, nitrogen dioxide $23.4 \%$, carbon dioxide $19.05 \%$, nitrogen oxide $18.76 \%$, phenol $7.03 \%$, formaldehyde $-5.12 \%$.At point II, the contribution of nitrogen dioxide to the risk of chronic intoxication comprised $26.07 \%$, suspended substances - $25.84 \%$, carbon monoxide $-21.09 \%$, nitrogen oxide $9.39 \%$, phenol $-8.21 \%$, formaldehyde $-6,34 \%$. At point III, the contribution of formaldehyde to the risk of chronic intoxication is significantly higher and reaches $21.33 \%$, the contribution of suspended solids is $18.31 \%$, nitrogen dioxide is $18.20 \%$, phenol is $18 \%$, carbon monoxide is $17.78 \%$, nitric oxide $-4.5 \%$.

Carcinogenic risk was estimated from concentrations in the ambient air of formaldehyde, benzpyrene, and metals (chromium, nickel, lead). The greatest danger to the health of the population from the assessment of carcinogenic risk is chromium and formaldehyde. At point I, the contribution of chromium is $57.34 \%$, formaldehyde $-40.37 \%$. At point II, the contribution of chromium is $59.07 \%$, formaldehyde $-38.56 \%$. At point III, the contribution of chromium in the total carcinogenic risk is less and comprises $41.72 \%$, at that the contribution of formaldehyde reaches $56.33 \%$.

The results of the study are summarized in the following conclusions:

1. The level of pollution in the central part of the city is determined by the indicator $P$ (average annual concentrations) 1.5 times higher than in a relatively clean northern residential area.

2. The risk of immediate action in the central part of the city is 3.38 times higher, the risk of chronic intoxication is higher in 2.05 times, in comparison with the northern residential area.

3. According to the results of the risk assessment on immediate action and chronic intoxication from air pollution, the most dangerous to the health of the population are suspended substances, nitrogen oxides, carbon monoxide, phenol and formaldehyde.

4. Chromium and formaldehyde mainly contribute to the formation of carcinogenic risks from the air pollution.

\section{Лumepamypa}

1. Ежегодник «Состояние загрязнения атмосферы в городах на территории России» за 2008 - 2013 гг. [Электронный ресурс] / ФГБУ «Главная геофизическая обсерватория им. А.И. Воейкова», Росгидромет. СПб., 2008-2013 гг. Режим доступа: http://www.voeikovmgo.ru/index.php?option=com_content\&view=article\&id=40:perech en-materialov-izdannykh-ggo\&catid=41\&ltemid=24\&lang $=$ ru.

2. Окружающая среда и здоровье: подходы к оценке риска. СПб., 2002.

3. Онищенко Г.Г. Городская среда и здоровье человека // Гигиена и санитария. 2007. № 5.

4. Онищенко Г.Г., Новиков С.М., Рахманин Ю.А. Основы оценки риска для здоровья населения при воздействии химических веществ, загрязняющих окружающую среду. М., 2002.

5. Рахманин Ю.А. Оценка ущерба здоровью человека как одно из приоритетных направлений экологии человека и инструмент обоснования управленческих решений // Гигиена и санитария. 2006. № 5.

6. Рахманин Ю.А. Современные направления методологии оценки риска // Гигиена и санитария. 2007. № 3.

7. Экологический вестник Дона за 2008 - 2013 гг. [Электронный ресурс] / Правительство Ростовской области. Комитет по охране окружающей среды и природных ресурсов Ростовской области. Ростов-на-Дону, 2009-2013 гг. Режим доступа: http://xn--d1ahaoghbejbc5k.xn--p1ai/state-of-the-environment/ekologicheskiy-vestnik/ 


\section{References}

1. Annual"Air pollution state in cities on Russia territory" for 2008-2013. [Electronic resource] / FSBU“Main geophysical observatory named after A.I.Voyeikov", Rosgydromet. SPb., 2008-2013.Access mode:

http://www.voeikovmgo.ru/index.php?option=com_content\&view=article\&id=40:perech en-materialov-izdannykh-ggo\&catid=41\&ltemid=24\&lang $=$ ru.

2. Environmentand health: approaches to the risk estimation. SPb., 2002.

3. Onishchenko G.G. Urban environment and person's health // Hygiene andsanitary. 2007. No 5.

4. Onishchenko G.G., Novikov S.M., RakhmaninYu.A. The basics of risk assessment for public health under the impact of chemicals polluting the environment M., 2002.

5. Rakhmanin Yu. A. Assessment of damage to human health as one of the priority areas of human ecology and a tool for management decisions justifying // Hygiene and sanitary. 2006. No 5.

6. Rakhmanin Yu. A. Modern directions of risk assessment methodology // Hygiene and sanitary. 2007. No 3.

7. The ecological vestnik of the Donfor 2008 - 2013. [Electronic resource] / Government of the Rostov Region. Committee for Environmental Protection and Natural Resources of the Rostov Region. Rostov-on-Don, 2009-2013.access mode: http://xn-d1ahaoghbejbc5k.xn--p1ai/state-of-the-environment/ekologicheskiy-vestnik/ 